Changing Incidence of Congenital Pyloric Stenosis in Barbados

SIR,-A study of the records of the paediatric department of the Queen Elizabeth Hospital, Barbados, where I was recently resident for a year, shows that there has been an increase in the incidence of congenital pyloric stenosis in the island in recent years. During the period 1963-8 only two cases occurred, both in 1967. There was one case in 1969, two in each of the next three years, and seven in 1973 (up to October). Of the total of 16 cases, 14 were in males-11 of them the firstborn. All but two of the infants were Negroes. The history was typical in each case; two infants were noted to have accompanying jaundice. The diagnosis was confirmed at operation in all cases. One child died a day later; this infant was severely malnourished and dehydrated on arrival in hospital.

Barbados has a population approaching a quarter of a million. There is relative ease of communication. Health care is free at the Queen Elizabeth Hospital. Congenital pyloric stenosis tends to run an unremitting course, and it is unlikely that an infant with persistent vomiting from pyloric stenosis missed the attention of the three consultant paediatricians on the island. The birth rate has tended to decline slightly over the past 10 years. The population of the island is divided into an ethnic pattern of $89 \%$ Negro, $4 \%$ White, and the remainder mixed races.

The figures are presented in that they dispute previous reports in the literature of the rarity of pyloric stenosis in Negroes, while it it also interesting to speculate whether the rise could be attributed to some external stimulus of recent introduction to the general population. The relative rarity of pyloric stenosis in African infants was reported by Swan, ${ }^{1}$ whose findings are supported by figures from the West Indies and the United States. Some paediatricians however, such as Schaffer from Baltimore, ${ }^{2}$ have recorded the impression of a decline in the incidence of pyloric stenosis. As discussed above, it is unlikely that previously missed cases are now being detected in Barbados. The island has undergone increasing urbanization in recent years, and mothers and children are enjoying the diets of the developed countries, but it is hard to identify the aetiological factor responsible for such a dramatic increase in cases. Whether the increase is a real one can be shown only by a study of the incidence in future years, but pyloric stenosis can no longer be considered a rarity in Barbados.

I would like to thank Dr. A. C. Graham for allowing me to report on his cases, and for his helpful advice.

-I am, etc.

DAvid E. MURFIN

Swansea

1 Swan, T. T., British Medical fournal, 1961, 1, 2 Schaffer, A. J., and Avery, M. E., Diseases of the Newborm, 3rd edn., p. 296.' Philadelphia,
Saunders, 1971.

\section{Dementia in the Elderly}

SIR,-I have noticed a slip in my article an this subject (8 December, p. 602) which needs correction. Having spoken of the usefulness of thioridazine and chlorpromazine by mouth $I$ go on to mention both drugs in the context of parenteral administration.
Thioridazine, however, is not available for injection and $I$ am afraid its repetition in that context was an unintentional clinical example of the "perseveration" which is a feature of the condition that the article was about.-I am, etc.,

Goodmayes Hospital,

TOM ARIE Ilford, Essex

SIR,-As an addition to Dr. Tom Arie's excellent survey of investigations (1 December, p. 540) may I mention that blood plateet electrophoresis is a useful and relatively simple test to differentiate neurogenic from arteriosclerotic dementia?'-I am, etc.,

\section{Langthorne Hospital,}

1 Szanto, S., Age and Ageing, 1972, 1, 207.

STEPHEN SZANTO

\section{Acute Transient Polyneuritis Associated with Oral Contraception}

SIR,-We wish to report a very rare possible complication of oral contraception. A 23year-old healthy woman had taken Enavid (mestranol $0.075 \mathrm{mg}$ and norethynodrel $5 \mathrm{mg}$ in each pill) cyclically for six months until nausea appeared. Two years later she started taking Sequelan (mestranol $0.1 \mathrm{mg}$ in the first 15 pills and mestranol $0.075 \mathrm{mg}$ and norethynodrel $5.0 \mathrm{mg}$ in the last five in each series). After three days she experienced mild plantar pain and paraesthesiae which increased rapidly in intensity and exten above ankles, and drug intake was therefore suspended after the 15 th pill. At that time there was marked pain in the feet with difficulty in walking and hypaesthesia to pain in a stocking-like fashion up to the ankles. The erythrocyte sedimentation rate was 45 $\mathrm{mm}$ in one hour and $68 \mathrm{~mm}$ in two hours, the total leucocyte count $9,400 / \mu \mathrm{l}$, and the eosinophil count $6 / \mu \mathrm{l}$. The glucose tolerance test was normal. The motor conduction in the peroneal nerve was $38 \mathrm{~m} / \mathrm{sec}$. with splitting of the potential and low amplitude. Within three weeks pain disappeared and walking was normal, though hypaesthesia to pain persisted in her feet. The motor nerve conduction in the common peroneal nerves returned to normal $(46 \mathrm{~m} / \mathrm{sec})$.

Among the possible pathogenetic mechanisms which can be thought of as responsible for the development of peripheral neuropathy, we are most inclined to incriminate an allergic sensitization to mestranol The present case strongly resembles the one reported by Strang ${ }^{1}$ in 1965 , and this tends to diminish the possibliity of a possible coincidental occurrence of an infective polyneuritis.-We are, etc.

I. EIBSCHITZ

Departments of Obstetrics and Gynaecology

B. SHARF

and Neurology,

Rothschild University Hospital,

Israe

Strang,
879.

\section{One Thousand Vasectomies}

SIR,-While I was most interested to read the article by the staff of the Margaret Pyke Centre (27 October, p. 216), I was shocked to read Mr. I. G. Schraibman's riposte in the issu: of (17 November p. 418). Vasectomy never needs to be done under general anassthes.a on a heal:hy man except for re-exploration of a previous operation, and the removal of $7.5 \mathrm{~cm}$ of vas is completely contrary to the unanimous resolution of the Second Interna ional Conference on Sterilization held in Geneva in February 1973. This stated that the opera:ion must always be done bsaring in mind the possible necessity for future reanastemosis should the patient remarry, and it thus follows that a minimal amount of vas must be destroyed compatible with an effective operation, so that a repair operation can in fact be undertaken if required at a later date.

Over 5,500 patients have had vasectomies at the Marie Stopes Memorial Centre, all of them under local anaes:hesia, and we have long ago completely abandoned the use of non-absorbable sutures as these tend to cut out and form stitch abscesses. The presence of semen 12,14, and 15 months after operation respectively in three cases out of $\mathrm{Mr}$. Schraibman's series of 223 is no improvement on previous reports and certainly cannot justify subjecting these patients to the disadvantage of painful mobilization of the vas and increased postoperative pain or the use of valuable hospital beds and theatre and anaesthetists' time, quite apart from the vastly increased cost of the operation.

The actual necessity for removing any of the vas has not been definitely established and $S_{c h m i d t}{ }^{1}$ does not remove any vas; instead he cuts it across and coagulates the lumen on each side with diathermy. He claims never to have had any failures.

There is no conclusive evidence that tying back the ends is an improvement, and Marshall and Lyon $^{2}$ record a case where recanalization took place after a section of vas had been removed, the lumina had been coagulated with diathermy, and the ends ligated with silk after being turned back.

That vasectomy can readily and efficiently be undertaken as a quick, simple, and permanent form of contraception by a trained, competent, and experienced general practitioner in the context of family planning in suitable premises has been amply demonstrated $^{3-8}$ and one wonders how the use of hard-pressed and expensive hospital resources can possibly be justified for the sake of unnecessarily removing $7.5 \mathrm{~cm}$ of vas and subjecting the patient to pain and discomfort and loss of work.-I am, etc.,

London $\mathbf{W} .1$

Michael Altman

1 Schmidt, S. S., Fournal of the American Medical Association, 1971, 216, 522 .

Marshall, S., and Lyon, R. P., Fournal of the American Medical Association, 1972, 219, 1753. Altman, M., British Medical fournal, 1972, 1 ,

Hobbs, J. J., British Medical fournal, 1972, 1,

802.
Altman, M., Medical News-Tribune, 21 January,

Peel, J., and Potts, M., Textbook of Contraceptive 1969.

Collow-up of a Thousand Cases.

8 Nicholas, P., and Nicholas, S., British Medical fournal, 1972, 1, 377.

\section{Anticonvulsant Hypomagnesaemia}

SIR,-The occurrence of osteomalacia in epileptics on anticonvulsant therapy is well established, as is the effect of vitamin $D$ in such patients. Intestinal magnesium absorp- 


\begin{tabular}{|c|c|c|c|c|c|c|c|c|c|}
\hline & & & \multirow{3}{*}{ Nn } & \multicolumn{6}{|c|}{ Serum Magnesium Concentration } \\
\hline & & & & \multicolumn{3}{|c|}{$\mathrm{mmol} / 1$} & \multicolumn{3}{|c|}{$\mathrm{mmol} / 100 \mathrm{~g}$ protein } \\
\hline & & & & Mean & S.D. & $\begin{array}{c}\text { Significance of } \\
\text { difference from } \\
\text { normal mean }\end{array}$ & Mean & S.D. & $\begin{array}{l}\text { Significance of } \\
\text { difference from } \\
\text { normal mean }\end{array}$ \\
\hline $\begin{array}{l}\text { Group A } \\
\text { Group B } \\
\text { Group C }\end{array}$ & $\begin{array}{l}\cdots \\
\cdots \\
\cdots\end{array}$ & $\begin{array}{l}\cdots \\
\cdots \\
\cdots\end{array}$ & $\begin{array}{r}151 \\
16 \\
59\end{array}$ & $\begin{array}{l}0.77 \\
0 \cdot 79 \\
0.78\end{array}$ & $\begin{array}{l}0.05 \\
0.05 \\
0.05\end{array}$ & $\begin{array}{l}P<0.001 \\
\text { N.S. } \\
P<0.001\end{array}$ & $\begin{array}{l}1.04 \\
1.02 \\
1.04\end{array}$ & $\begin{array}{l}0.08 \\
0 \cdot 10 \\
0 \cdot 10\end{array}$ & $\begin{array}{l}P<0.001 \\
P<0.02 \\
P<0.01\end{array}$ \\
\hline All epileptics & . & $\ldots$ & 226 & 0.78 & 0.05 & $P<0.001$ & 1.04 & 0.09 & $P<0.001$ \\
\hline Control subjects & . & . & 95 & $0 \cdot 81$ & 0.04 & & 1.08 & 0.07 & \\
\hline
\end{tabular}

Group A: Patients treated with phenytoin.

Group A: Patients treated with phenytoin.

Group C: Patients treated with phenytoin and phenobarbitone or phenytoin and primidone.

N.S. = Not significant $(P>0.05)$

tion, like calcium absorption, tends to increase after vitamin $\mathrm{D}$ administration $;^{2}$ and vitamin $\mathrm{D}$ deficiency is accompanied by impairment of both calcium and magnesium absorption. ${ }^{3}$ It is known that children with florid rickets often exhibit hypomagnesaemia in addition to hypocalcaemia. After completing our recentiy published article on anticonvulsant osteomalacia ${ }^{1}$ we have investigated the possib:lity that epileptic patients on anticonvulsant therapy show hypomagnesaemia.

Serum magnesium was determined by atomic absorption spectrophotometry (Perkin-Elmer, model 403) and serum protein refractometrically in the 226 epileptics and 95 control subjects, details of whom have been given. ${ }^{1}$ Mean duration of anticonvulsant treatment was seven years. The coefficient of variation of duplicate measurements of serum magnesium was $0.9 \%$ and of serum protein $0.3 \%$. The results are given in the table. The epileptics had serum magnesium concentrations significantly lower than the control subjects, whether the concentrations were expressed as $\mathrm{mmol} / \mathrm{l}$. or as $\mathrm{mmol} / 100 \mathrm{~g}$ serum protein. Fourteen and $12 \%$ of the patients had a serum magnesium concentration below the normal range (mean \pm 2 S.D.) in terms of $\mathrm{mmol} / \mathrm{l}$. and $\mathrm{mmol} / 100 \mathrm{~g}$ serum protein respectively. Accordingly, the lower serum magnesium concentration in the epileptics was not due to differences in serum protein concentrations and protein-bound magnesium. Serum magnesium was not correlated to serum calcium nor to the duration of anticonvulsant therapy.

Lowering of the magnesium concentration in extracellular fluid would tend to increase neuromuscular irritability and is therefore probably an undesirable side effect of anticonvulsant therapy. The clinical significance of such minor degrees of hypomagnesaemia in epileptic patients remains to be established.-We are, etc.,

\section{Christiansen}

Department of Clinical Chemistry, PoRS NIELSEN Department of Clinical Physiology, Glostrup Hospital,

Glostrup

Department of Clinical Physiology,

P. RøDBRO

Aalborg Sygehus Syd,

Aalborg, Denmark

1 Christiansen, C., Rodbro, P., and Lund M., British Medical fournal, 1973, 4, 695.

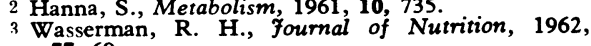
$77,69$. Hüther, W., Monatsschrift für Kinderheilkunde,
1964, 112, 16.

\section{Adverse Reactions to Alclofenac}

SIR,-The intent of Dr. D. Mansel Jones's letter (26 January, p. 160) is fully supported by this company, which has co-operated with his colleagues in the exchange of information on adverse reactions.

Our data sheet on alclofenac is currently under revision, but present circumstances will produce a delay in the distribution of this to prescribers. May we, therefore, use your columns to point out that this company considers the role of alclofenac is in the treatment of the chronic arthritides, where it is being shown to be of particular value and safety in long-term treatment. To our knowledge, all adverse reactions have occurred in the first three weeks of treatment, while treatment over months and years has not been accompanied by any sign of toxicity. We would appreciate receiving any information that appears to contradict this statement.-I am, etc.,

J. F. HORT

Berk Pharmaceuticals Ltd. Medical Director

Godalming, Surre

\section{Fluoride and Osteoporosis}

SIR,-We feel compelled to reply to the comments by Drs. J. Dequeker and A Burssens (3 March 1973, p. 551). They make three main criticisms of our report on the treatment of osteoporosis with fluorides ${ }^{1}$ : they question the diagnosis in our cases, our choice of fluoride dosage, and the validity of our measurements. All of our 11 patients had the syndrome of postmenopausal osteoporosis as defined by Albright, and they did not have osteomalacia. We have previously reported $^{2}$ that osteoid borders are somewhat wider in osteoporotic persons than in control persons of the same age, but the width is still significantly less than that found in clinical osteomalacia.

One of the purposes of our study was to determine the optimum dose of sodium fluoride for effective treatment. The dose was chosen as $50 \mathrm{mg}$ of sodium fluoride daily because this was approximately halfway between the ineffective dose, less than $45 \mathrm{mg}$, and the maximum, $60 \mathrm{mg}$, which may lead to an undesirable effect on mineralization of new bone. Monitoring serum fluoride values might be of value, particularly because the intestinal absorption of fluoride is variable, but this is both tedious and impracticable in a large group. As Drs. Dequeker and Burssens state, renal sclerosis decreases fluoride elimination. Our patients were noted to have normal renal function. Indeed, the use of sodium fluoride and, more particularly, the administration of large doses of vitamin $\mathrm{D}$ and calcium would be contraindicated if there were any evidence of impaired renal function.

Finally, Drs. Dequeker and Burssens have made an error in questioning the validity of our quantitative values. Estimates of error are expressed as percentages of the absolute values. In this case the absolute values of our measurements are also percentages (percentage of total surface). Thus the increase in bone formation that we reported, $4.4 \%$ in absolute terms, is approximately $100 \%$ in terms of the percentage differences. In addition, measurement errors are generally random and the $P$ value of less than 0.001 indicates a highly significant, non-random difference between the before-treatment and after-treatment values for bone formation.We are, etc.,

JENIFER JOWSEY

B. LAWRENCE RIGGS Patrick J. Kelly

Mayo Clinic and Mayo Foundation

Rochester, Minnesota

1 Jowsey, J., Riggs, B. L., Kelly, P. J., and Hoffman, D. L., American Fournal of Medicine, man, 53,43 .

Jownson, K. A., Riggs, B. L., Kelly, P. J., and 1971, 33, 745.

\section{New Constant Positive Pressure Respiration} Apparatus

SIR,-Gregory et al..$^{1}$ described a method whereby constant positive pressure respiration is made possible for the newborn infant, making use of the simple apparatus described by them. There are, however, two major disadvantages in Gregory's method: (1) tracheal intubation in the neonate for an extended period of time is hazardous; and (2) the aneroid manometer is adversely affected by high humidity, and personal observation has shown that very often the pressures indicated are incorrect. The former pitfall may be avoided by the use of the Bennet face mask, and the latter by using a water manometer.

A simple and highly effective apparatus (see fig.) has been designed and has been in use in our department for more than a year. It consists of: a U-tube (a), with scale for reading off the positive pressures attained in the system; an escape valve $(b)$ for regulating these pressures; connecting tubes (Bird) (c) from the above to the Bennet face mask; (d) and an anaesthetic bag and connecting gas line $(e)$ from an air $/ \mathrm{O}_{2}$ blender.

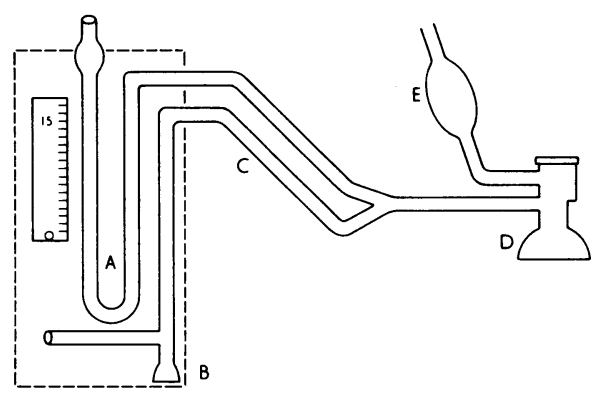

The U-tube and escape valve are assembled on a plastic board fitted with a Gabler snaplock to fit a Gabler wall rail. The Bennet face mask is applied snugly to the patient's face. The constant positive pressure is adjusted according to the needs of the patient.

The apparatus has been used with success in our neonatal units and is a very effective, simple, and cheap method of treating the idiopathic respiratory distress syndrome of the neonate weighing more than $1,500 \mathrm{~g}$. We 